Fifth International Conference on Sustainable Construction Materials and Technologies. http://www.claisse.info/Proceedings.htm

\title{
TECHNICAL-FINANCIAL VIABILITY OF THE SUSTAINABLE GUIDELINES IMPLEMENTATION RELATED TO WATER AND ELECTRICITY FOR SCHOOLS.
}

\author{
Amanda Francielle do Nascimento ${ }^{1}$ \\ Maria Julia Pereira ${ }^{2}$ \\ Rúbia Bernadete Pereira dos Santos ${ }^{3}$
}

1254 Arnaldo José de Oliveira street, Fazenda, 88302-300, Itajaí, Santa Catarina, Brasil, amandanascimento@edu.univali.br, Civil Engineering student at Universidade do Vale do Itajaí - UNIVALI.

2136 João Melquiades Fernandes street, São João, 88304-560, Itajaí, Santa Catarina, Brasil, mjuliapereira@edu.univali.br, Civil Engineering student at Universidade do Vale do Itajaí - UNIVALI.

3425 Juvenal Garcia street, Centro, 88302-040, Itajaí, Santa Catarina, Brasil, rubiasantos@univali.br, MSc Civil Engineer and Civil Engineering professor at Universidade do Vale do Itajaí - UNIVALI.

\begin{abstract}
In schools, it is observed a great water and energy consumption, due to the number of people and length of stay on site. And it is a place where there is a high potential for the school community awareness and propagation to society. This study determined the technical-financial viability of the sustainable guidelines implementation related to water and electricity for the municipal education network schools of Camboriú/SC. To do so, a school was used as a reference, where the consumption of water and electricity data were collected; dimensioning a generic project with its respective costs. A trend simulation was established for the other schools. The implemented guidelines in the educational network can reduce annual energy consumption by $19.35 \%$ and water by $76.86 \%$, with investment return in 9.67 years. Contributing to make the city more sustainable, besides favoring the consumer in cost reduction.
\end{abstract}

Keywords: Energy consumption, technical-financial viability.

\section{INTRODUCTION}


The sustainable development sense was presented as a counterpoint to unbridled population growth, the ever-increasing need to produce and consume. Thus, waste and pollution gained space, and the negative impacts generated by human beings began to affect the environment. That was when that in the 70's decade, through the Stockholm Conference, that socio-environmental issues began to be effectively discussed.

In addition, economic development is direct and/or indirectly related to socioenvironmental impacts. In this scenario, the construction industry is one of the sectors that most contribute to environment degradation. Baptista Junior and Romanel (2013, p. 29) confirm that "the environmental impact caused by the production and disposal of the construction industry waste is one of the planet's principal, either by the amount daily discarded or by the natural resource deposits' irrational use."

Therefore, construction workers, according to Ching and Shapiro (2017, p. 257) have to "[...] make a decision: to bear the responsibility of the climate change impacts caused by buildings or lead the necessary change to reduce the buildings impacts on climate change."

On this basis, it is must need to implement sustainable construction. As with other constructions, the schools, being public spaces, must be sustainable, since they are buildings, often of large size, that daily accommodate hundreds of people, besides having the role of training and educating. Therefore, implementing the sustainability practice in schools is paramount.

A person spends about twelve years in a school, the equivalent of 2,400 days, this considering the first year of elementary school to the third year of high school. Thus, throughout his/her school life, he/she will use approximately 60 thousand liters of drinking water and 9,600 hours of electricity.

A school with sustainable practices is able to guarantee the school community participation (students, parents, employees) and propagate these principles. This involvement guarantees the implemented guidelines' knowledge, ensuring sensitization and awareness of an increasing number of people.

The sustainable habits promoted in school are possible to be disseminated with more facilities and in this way be repeated by the people who live in such an environment. Besides this, the guidelines implemented in schools are more likely to be introduced in other places, making the municipality more sustainable.

It is important to understand that the guidelines under studyfor school units do not on ly have the focus of benefiting them, but rather contributing to the whole society.

Since the conception of a sustainable project is manifested by defending the main concept of sustainability, meeting current needs without compromising future generations.

This article aims to determine the technical-financial viability of the sustainable guidelines implementation related to water and electricity for schools.

\section{BACKGROUND}

In 2015, the UN established the Sustainable Development Goals (SDGs), such goals were built from the Millennium Development Goals (MDGs), and aim to conclude the work of the MDGs. They are integrated and indivisible and balance the three dimensions of sustainable development: the economic, social and environmental. (UN, 2015). 
These goals form an agenda, named "Transforming our World: the 2030 Agenda for Sustainable Development." The UN $(2015$, p. 1) affirms that "This Agenda is a plan of action for people, planet and prosperity."

The reference document (2015) still reports that the SDGs are composed of 17 goals, totaling 169 targets, and aims to stimulate action over the next fifteen years in areas of critical importance for humanity and the planet.

Figure 1 - Sustainable Development Goals (SDGs).
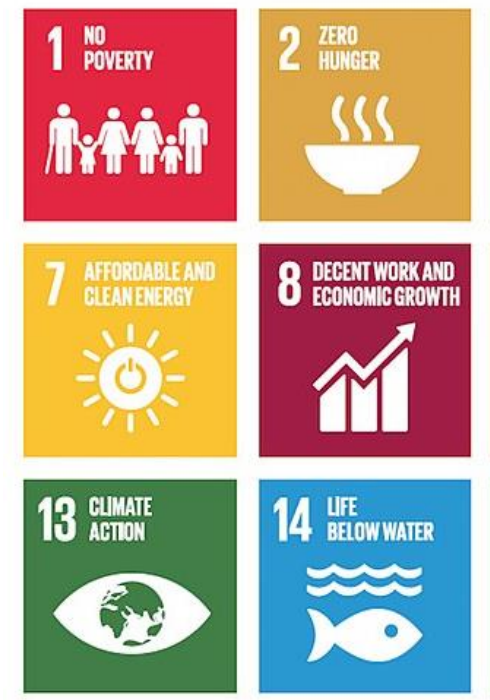
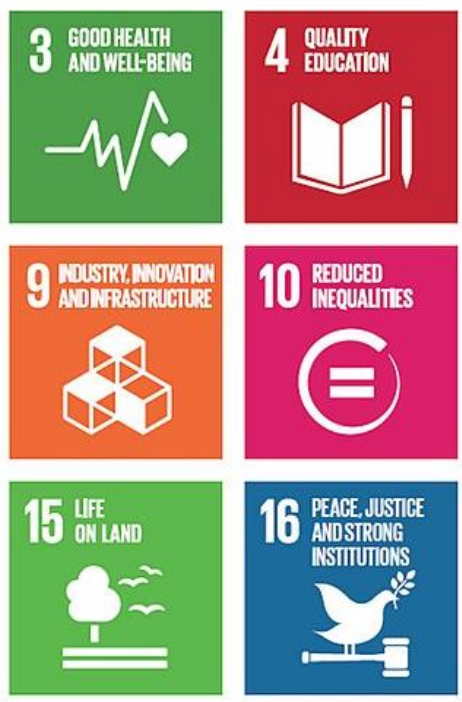
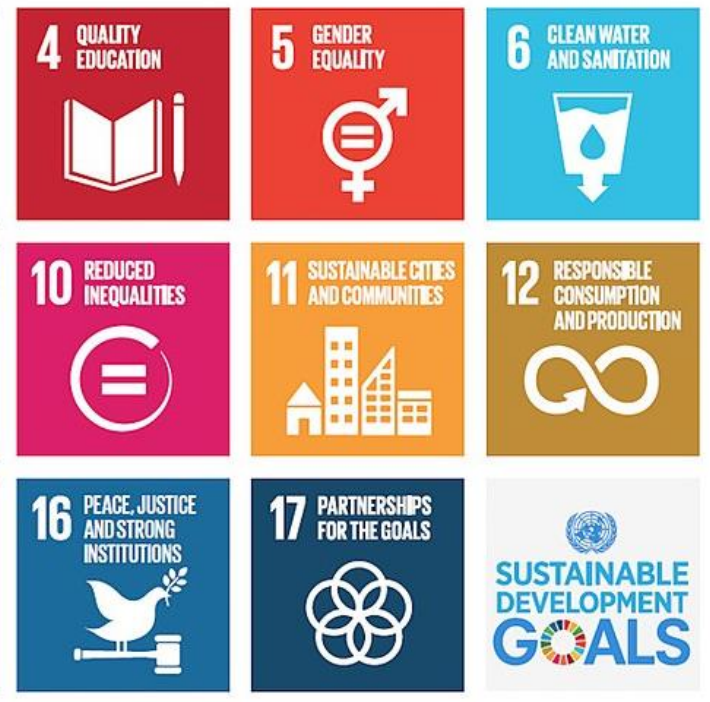

(9)

SUSTAINABLE DEVELOPMENT GEv" ALS

Source: UN, 2015.

To ensure that the planet meets the needs of the present and future generations, through the natural resources sustainable management, protecting it against degradation, is one of the purposes established by the SDGs.

According to Ching and Shapiro (2017, p. 14) "[...] a sustainable building is the one that has a significantly reduced environmental impact and provides internal environments that are beneficial to people's health."

The objectives introduction, 6 referring to drinking water and sanitation, and objective 7 related to clean and accessible energy, through the sustainable guidelines implementation in buildings, is able to soften the environmental impacts. The guidelines propagation makes the municipality more sustainable, thus guaranteeing objective 11, referring to sustainable cities and communities.

The capture and use of rainwater are capable of minimizing the water scarcity effects in large urban centers and decrease water expenditures (Mierzwa et al., 2007). The system can be installed herewith the green roof since the vegetation layer contributes as a flow filter (Moreira, 2012).

The green roof also helps to decrease the heat incidence on the construction (Moreira, 2012). As well, adhering to the light colors in the building minimizes the heat absorption (Romero, 2007). Choosing more reflective surfaces for interior finishes would also require a smaller amount of energy sources without affecting lighting levels (Ching \& Shapiro, 2017). Thus increasing energy efficiency.

It is important to highlight that on an urban scale, the green roof is able to reduce the city temperature (Bueno, 2010). Just like the white roof, it can reduce summer energy use by 10-40\%, besides reducing the Urban Heat Island effect (White Roof Project, n.d.). 
The urinal without water as its name already says, does not need water for its operation, which guarantees an economy in the monthly water bill, offering a return period of 6 to 8 months (Kurle, 2018). The water consumption reduction can also be achieved by reducing the rate or the duration of the flow (Ching \& Shapiro, 2017).

LED bulbs have low energy consumption, greater durability and lower environmental impact (Instituto Nacional de Metrologia, Qualidade e Tecnologia - INMETRO, n.d.). Also contributing to an energy efficiency increase. In addition to the LED lamps, the presence sensor also presents itself as an option to be studied for the reduction of the lighting systems operation in schools (Secretaria de Energia e Mineração do Governo de São Paulo, n. d.). With an electricity economy of up to $75 \%$ (EXATRON, n. d.).

\section{METHODOLOGY}

The study was carried out at the Domingos Fonseca Municipal Basic School, located at 1040 Marmeleiro street, Tabuleiro, Camboriú. The city of Camboriú is located on Santa Catarina state coast and is part of the Itajaí valley.

The school, built in 2009 , has two floors of $833.70 \mathrm{~m}^{2}$ each, in addition to a large indoor court of $464.94 \mathrm{~m}^{2}$, built on a ground of $1,866.28 \mathrm{~m}^{2}$, where it accommodates daily 612 students enrolled from 1 st to 5 th grade.

Its structure has 13 classrooms, being one specific for arts class, 1 indoor court, 1 kitchen with pantry, service area and staff's toilet, 1 indoor cafeteria, 3 female toilets, 3 male toilets and 2 adapted toilets for students, 1 Physical Education deposit, 1 pedagogics room, 1 library, 1 secretariat with meeting room, board office and 2 teachers' toilets.

Besides the M.B.S. Domingos Fonseca, Camboriú has 29 more educational units, which, through simulation, were studied to determine the technical-financial viability of the sustainable guidelines implementation in the municipal education network.

\section{STAGE A) Project guidelines proposition for the school unit}

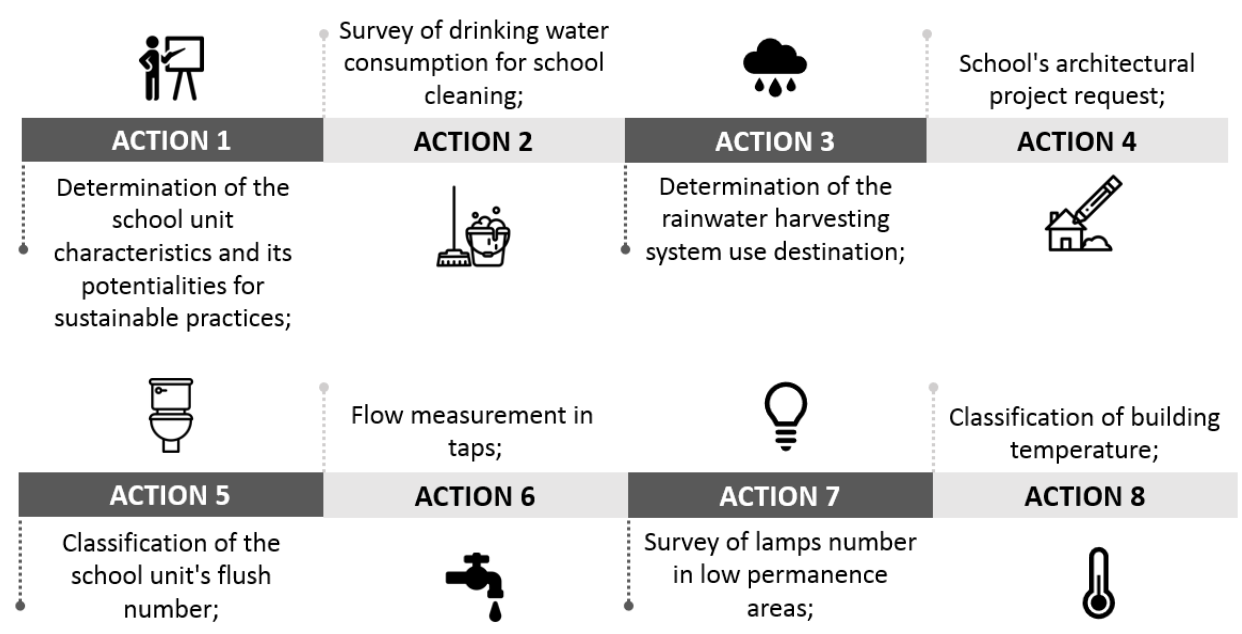




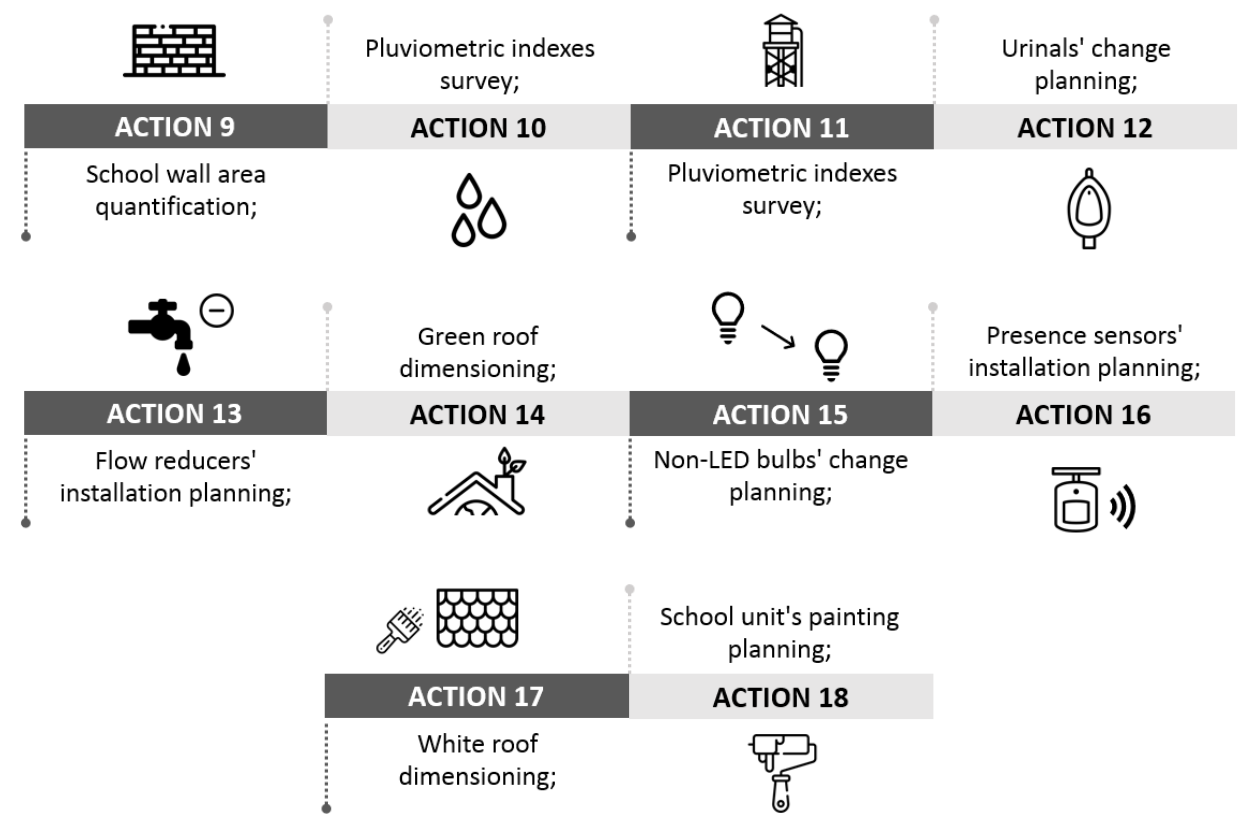

STAGE B) Establishment of sustainable systems implantation's cost for educational institutions

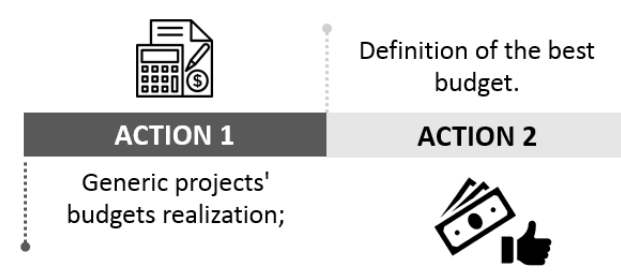

STAGE C) Time estimate that sustainable systems will take to restore investment

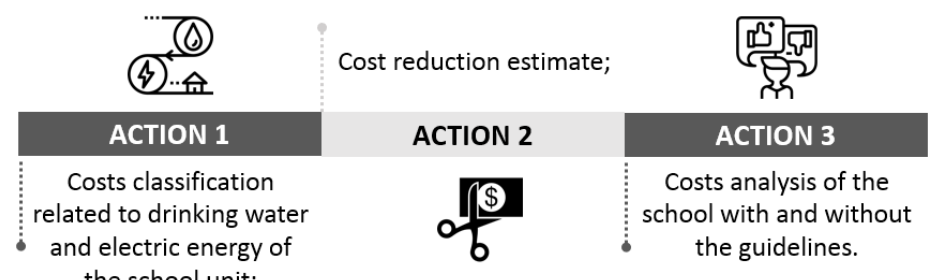

STAGE D) Simulation of the proposals for the other municipal school units 

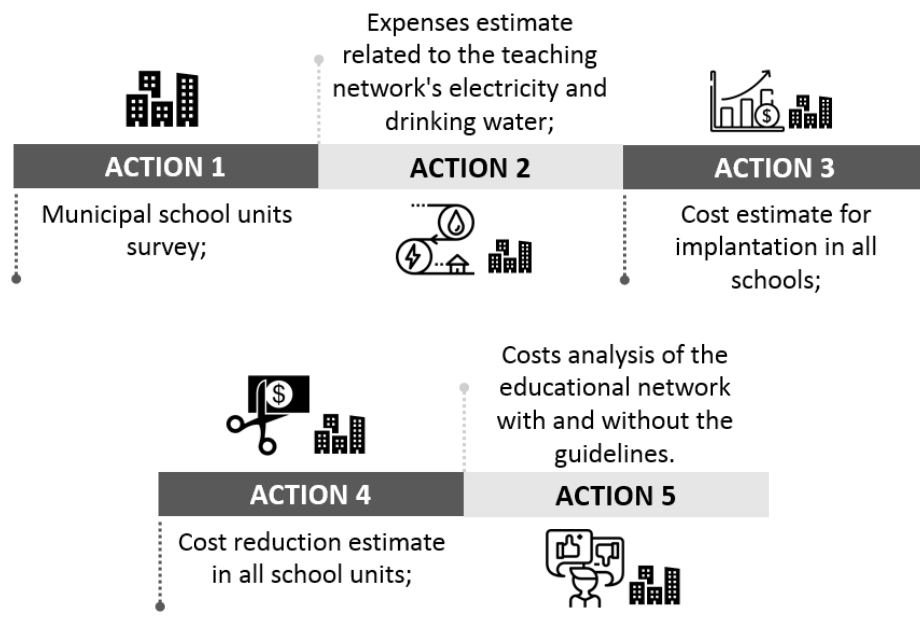

STAGE E) Agenda's elaboration with the sustainable development objectives for the municipal Education Network

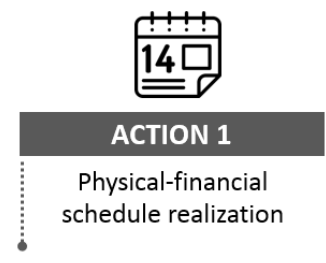

\section{ANALYSIS AND DISCUSSION OF RESULTS}

\section{Data Collection}

Having the reference choice, it was necessary to collect data, through visits to be used in the trend simulation. The school operates 10 hours a day, and throughout its operation, demands drinking water for the use of toilets and kitchen, and for the school cleaning and maintenance, being identified that the toilets flush and the school kitchen are the consumption sources with bigger drinking water waste.

In addition to the high consumption of drinking water, the school also presents a great electricity expense, referring to excessive artificial lighting in low permanence places, and the use of artificial climatization in summer. A significant factor in such consumption is the school painting, where $43.68 \%$ of its area has dark colors, which require greater heat absorption.

\section{Water and Electricity Costs}

Based on the values provided by the Education Secretariat, it was necessary to calculate the average, due to the difference found between the years 2017 and 2018, obtaining an annual expenditure of US\$7,857.18 with electricity and US\$2,762.12 
with drinking water, in this way, it is possible to determine the spent values for each consumption point.

Since the access to the consumption of kilowatt hours (kWh) was not obtained, the Energy and Mining Secretariat Manual of the São Paulo Government was used to estimate the electricity expenses. It was then found that $70 \%$ of the electric energy expenses came from lighting in the school unit.

In the water expenditure, the highest consumption point found was in flush, corresponding to $48.82 \%$, and secondly, the kitchen with $26.28 \%$. Demonstrating, that toilet flush refers to the main necessity for the implementation of rainwater harvesting, as mentioned by the employees during the interviews.

As the other points of consumption require drinking water, it was added to the rainwater harvesting the monthly demand for cleaning, where both demands totaling $90.51 \mathrm{~m}^{3}$ annual, which is equivalent to $57.81 \%$ of the building costs.

\section{Dimensioning}

Rainwater harvesting and harnessing: To begin dimensioning, it is necessary to first know the precipitation data of the closest meteorological station to the school, which were provided by EPAGRI. Knowing the monthly rainfall average, the catchment area and monthly demand, obtained by the monthly consumption of the toilet flush and the cleaning, it was possible to calculate the reservoir volume by the Rippl method and the simulation analysis method, thus achieving a $75 \mathrm{~m}^{3}$ reservoir.

Urinal without water: The corridors' toilets show in their layout besides sanitary pots, three urinals on each pavement, totaling in six urinals to perform the change in the school unit.

Flow reducers in taps: 21 flow reducers were implanted in the taps of toilets and kitchen.

Green roof: Considering that the system would decrease the surface runoff coefficient of the roofing for rainwater collection, since the runoff coefficient would pass from $0.95-0.90$ to $0.50-0.10$, since the system retains part of the water for its operation, reducing the harvesting water storage, and consequently damaging the guideline operation, it was considered only the skylight area, equivalent to $112 \mathrm{~m}^{2}$. Presence Sensor: 70 presence sensors were planned, according to the number of lamps in the low permanence places.

White roof: The white roof was dimensioned through the roofing total area of 1450.69 $\mathrm{m}^{2}$ existing in the building.

Painting: The municipal schools' façade must be standardized with the municipality's colors, thus, the new design maintains the standard colors, but predominates the white color, in order to reduce the heat absorption from the façade's surfaces and ensure greater inside reflectance, which will require a total $5,313.17 \mathrm{~m}^{2}$ of surface.

\section{Implementation Cost}


Each guideline was quantified through its generic dimensioning so that the total cost of each system could be calculated. For the budgets, it was used values found in the market, when available, and the others were taken from the SINAPI, referring to September 2018.

The green roof use was discarded due to the white roof show approximately a twenty times smaller cost.

\section{Viability}

Each guideline's economy was measured based on the theoretical background, except for the capture and use of rainwater, which was estimated evaluating the dimensioning by the simulation method, decreasing the annual demand for the supply obtained from water provided by the supply network annually. Graph 1 shows the investment cost's summary and the return time for each guideline.

Graph 1 - Systems viability.

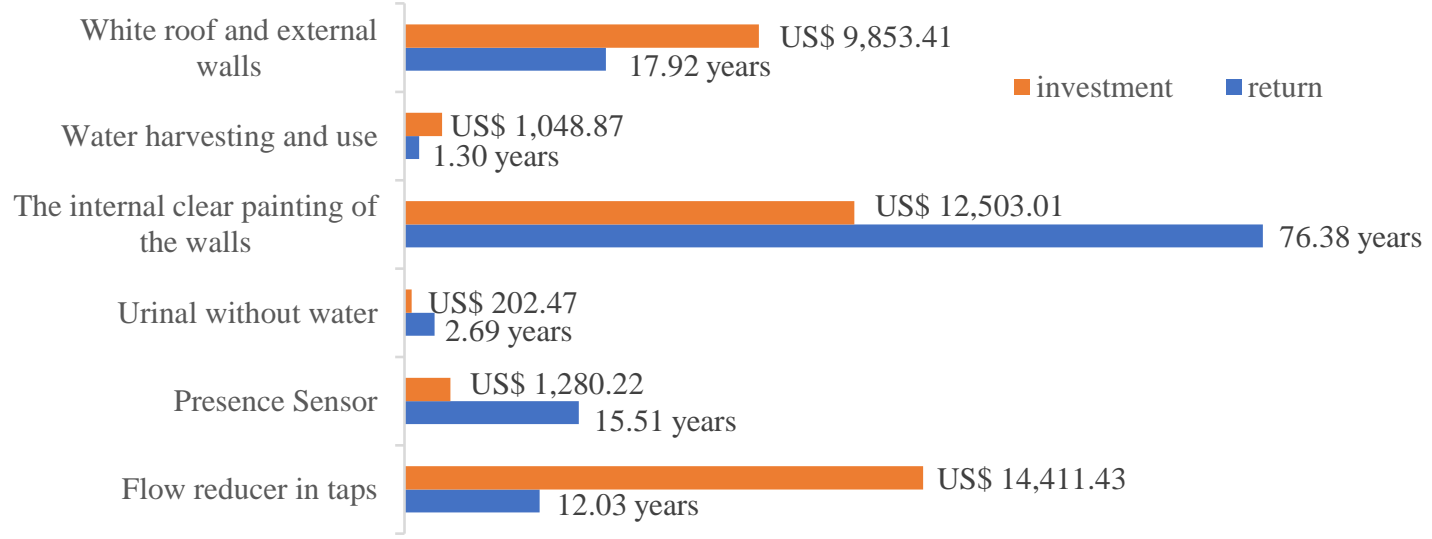

Source: The authors, 2018.

Flow reducer in taps: It is the system with lower cost, and second shortest return time, resulting in a $40 \%$ savings with the guideline implementation, reducing $20,73 \mathrm{~m}^{3}$ of drinking water and US\$ 365.70 annually.

Presence Sensor: Ranked second in terms of cost, and first in return time, presents a $50 \%$ reduction with the operation of the system, with a reduction of US\$ 806.93 referring to consumption with artificial lighting.

Urinal without water: positioned in third place according to the implantation cost and fourth place in return time, provides an economy with the guideline operation of $100 \%$ since the same does not use water, resulting in $4.68 \mathrm{~m}^{3}$ of drinking water reduction, equivalent to US $\$ 82.56$ per year. The return period can be justified by being a system deployed in locations that require low demand, compared to other systems.

The internal clear painting of the walls: in fourth place regarding the cost and fifth place in return time, it presents a $10 \%$ savings with the operation of the guideline, referring to the artificial lighting consumption, obtaining a reduction of US\$550.00 
per year. Its high return period can be justified by being a guideline applied in a large area, with localized cost reduction.

Water harvesting and use: Different from internal painting, the system is a guideline that presents a high cost reduction, but applied in a smaller area, ranked sixth and last place when it comes to implantation cost, and third place in return time, obtaining an economy with the system implementation of US\$ $1,432.32$ and $81.19 \mathrm{~m}^{3}$ of drinking water per year, the equivalent of $94.59 \%$. The high period is due to the high cost for reservoir construction, corresponding to $52 \%$ of its total investment.

White roof and external walls: ranked fifth in implementation cost and sixth and last place in return, the system presents a 50\% reduction with its implementation, referring to consumption with air conditioners in summer, a cost of US\$ 161.36 per year was reduced. With the guideline economy corresponding only to the summer, the reason for the high return period is justified.

It is perceived that façade's and internal's paintings, together were the guideline with the highest cost, this is due to the application being performed in the entire school unit structure, different from the other systems, which are implanted at punctual locations. However, such a system could be suppressed, because the painting is already included in the Municipal Education network budget as a school's maintenance, therefore, should not be considered an additional cost. In addition to this, white paints have a lower value than the colored ones, which would reduce the existing budget for renovations.

\section{Trend Simulation}

Based on the obtained data at the reference school, a trend simulation was elaborated for the other Camboriú's Municipal Education network units.

Camboriú's Municipal Education network has 30 schools, presenting approximately $45,597.72 \mathrm{~m}^{2}$ of built area and 13,902 students enrolled. M.B.S. Domingos Fonseca, the reference school, is the eighth largest school in constructed area and number of students enrolled.

The cost of drinking water and electricity in each school were obtained, totaling an annual expenditure of US\$ 71,521.72 in the educational network, referring to the demand of $48,650.30 \mathrm{~m}^{3}$ of drinking water, and US\$ $166,681.85$ relative to the electricity consumption.

The guidelines cost in each school unit was determined based on the budget realized for the reference school, totaling an investment of US\$ 836,282.58 for all schools.

The rainwater harvesting and utilization implementation was the guideline that presented the highest economy in relation to drinking water, with a $30,760.53 \mathrm{~m}^{3}$ consumption reduction of drinking water. Secondly, there are the flow reducers, and lastly, the urinals, totaling a $37,687.97 \mathrm{~m}^{3}$ economy, equivalent to US\$ 54,968.52 per year, resulting in a $76.86 \%$ expenditures reduction.

The presence sensor in a low-stay area was the system with the highest cost reduction related to electricity, obtaining an economy of US\$17,118.24 referring to the artificial 
lighting consumption. Secondly, there is the internal painting with a reduction also referring to the artificial lighting consumption. And lastly, the roof in conjunction with the white façade result in an economy corresponding to the air conditioning use in summer, the equivalent of a $19.35 \%$ expenditures reduction, with a total of US\$ $32,258.51$ per year.

Having the total cost of guidelines implementation in the educational network, and the economy's value generated per year in all schools, it was possible to calculate the return time of the investment. Based on $36.62 \%$ of savings per year, equivalent to US\$ $87,227.03$, the return time was estimated for each school, which resulted in 9.67 years for restitution of all systems in the educational network.

\section{Physical-Financial Schedule}

A plan was established to implement the guidelines, with their respective actions and costs, for a total of 12 years, deadline adopted to coincide with the UN's 2030 Agenda. The data obtained through the simulation were used to elaborate the physical-financial schedule. Each school's implementation time was determined through their respective areas, the higher the school, the more time to complete the reform and higher the cost.

\section{FINAL COMMENTS}

The present study development enabled the technical-financial viability analysis of the sustainable guidelines implementation related to water and electricity for schools. In addition, it also allowed conducting research to verify the waste main sources of such resources.

Given the importance of the subject, it is essential to spread sustainable practices, since the socio-environmental impacts are related to economic growth, once civil construction is considered one of the growth sectors of high economic level.

Furthermore, the planning and practice of a sustainable project allow the civil construction area to lead the necessary changes to reduce the impacts caused by the sector activities in climate change, thus defending the sustainability main concept.

By doing the first visit on site, it was found that schools have a high waste of drinking water and electricity, due to toilet flush, which represents the highest drinking water demand in the SU with 48.82\%, and artificial lighting, which characterizes the higher electricity's consumption with $70 \%$ of monthly demand.

To improve the construction's energy efficiency and the rational use of water in the school unit, it was proposed the implementation of project guidelines such as rainwater harvesting and utilization, urinal without water, flow reducers in taps, sensors of presence, white roof and paintings with light colors.

To implement the guidelines at M.B.S. Domingos Fonseca, the reference school, the cost will be US\$ 39,299.41, where the sustainable systems, together, will take approximately 9.67 years to restore the investment in the school, being the presence sensor, the guideline with less return time, and the white roof coupled with the clear painting of the façade, the systems with longer time.

When performing the simulations for the other municipality school units, a 4054.19 $\mathrm{m}^{3}$ monthly consumption of drinking water and an annual expenditure of US\$ 
238,203.57 referring to electricity and drinking water bills were verified. The proposals simulations for educational network obtained a total investment of US\$ $833,696.38$ with a return period of 9.67 years.

The sustainable guidelines implementation in the education network includes 12 years, with a monthly average cost of US\$ $5,789.56$, presenting a positive response to the municipality, with an annual economy of US\$ 87,227.03, corresponding to $36.62 \%$ of current expenditures, being $76.86 \%$ of water and $19.35 \%$ of electricity. However, if considering the painting budget included in the annual maintenance budget of the educational network, the return time would decrease considerably to 5.77 years, reducing the investment refund period by $41 \%$.

\section{REFERENCES}

Baptista Junior, J. V. and Romanel, C. (2018). Sustainability in the construction industry: a logistic for waste recycling of small works. [online] Scielo.br. Available at: http://www.scielo.br/pdf/urbe/v5n2/a04v5n2.pdf [Accessed 5 May 2018].

Bueno, R. (2010). Telhado verde: Os Jardins da Babilônia continuam funcionais. [online] Oecocidades.com. Available at: http://www.oecocidades.com/2010/page/10/ [Accessed 28 May 2018].

Ching, F. and Shapiro, I. (2018). Edificações Sustentáveis Ilustradas. 1st ed. Porto Alegre: Bookman.

Exatron (2018). [online] Exatron.com.br. Available at: http://www.exatron.com.br/files/uploads/products/MODELO-MANUALSPT0E27_3.pdf [Accessed 16 Jul. 2018].

Instituto Nacional De Metrologia, Qualidade E Tecnologia - INMETRO (n.d.). Lâmpada LED. [online] Available at: http://www.inmetro.gov.br/inovacao/publicacoes/cartilhas/lampadaled/lampadaled.pdf [Accessed 30 May 2018].

Kurle, M. (2017). Mictório sem água - como funciona. [video] Available at: https://www.youtube.com/watch?v=c3QIyWxJPXY\&t=5s [Accessed 18 Oct. 2018].

Mierzwa, J. et al. (2018). Águas pluviais: método de cálculo do reservatório e conceitos para um aproveitamento adequado. [online] Abrh.org.br. Available at:

https://www.abrh.org.br/SGCv3/index.php?PUB=2\&ID=69\&SUMARIO=842 \&ST=aguas_pluviais_metodo_de_calculo_do_reservatorio_e_conceitos_para_ um_aproveitamento_adequado [Accessed 29 May 2018].

Moreira, T. (2012). Vamos Cuidar do Brasil com Escolas Sustentáveis: educando-nos para pensar e agir em tempos de mudanças socioambientais globais.. [online] Ministério da Educação - SECADI. Available at: http://www.seduc.go.gov.br/documentos/nucleomeioambiente/material2013/ca derno.pdf [Accessed 9 Apr. 2018].

Organização Das Nações Unidas - ONU (n.d.). Transformando Nosso Mundo: A Agenda 2030 para o Desenvolvimento Sustentável. [online] Nacoesunidas.org. Available at: https://nacoesunidas.org/wpcontent/uploads/2015/10/agenda2030-pt-br.pdf [Accessed 24 Mar. 2018]. 
Romero, T. (2007). Cores que ajudam a economizar. [online] AGÊNCIA FAPESP. Available at: http://agencia.fapesp.br/cores_que_ajudam_a_economizar/8008/ [Accessed 28 May 2018].

Secretaria De Energia E Mineração Do Governo De São PAULO (2018). Manual de economia de energia elétrica na escola.. [online] Ecoreporter.abae.pt. Available at:

https://ecoreporter.abae.pt/docs/apoio/Manual_de_Economia_de_Energia_Eletr ica_na_Escola.pdf [Accessed 22 Aug. 2018].

Tomaz, P. (2010). Aproveitamento de água de chuva. [online] Pliniotomaz.com.br. Available at: http://www.pliniotomaz.com.br/downloads/livros/Livro_aprov._aguadechuva/ Livro Aproveitamento de agua de chuva 5 dez 2015.pdf [Accessed 24 Mar. 2018].

White Roof Project (n.d.). Telhado branco.. [online] White Roof Project. Available at: http://www.whiteroofproject.org [Accessed 12 Sep. 2018]. 